Economic Education Journal

Volume.1, Issu.1 January 2019, 15-29

http://ejurnal.ung.ac.id/index.php/jej

\title{
Identifikasi Faktor-Faktor Yang Mempengaruhi Motivasi Belajar Mahasiswa Pada Program Studi S1 Pendidikan Ekonomi Angkatan 2015 Fakultas Ekonomi Universitas Negeri Gorontalo
}

\author{
Israfani Logiswara Lagili', Usman Moonti ${ }^{2}$, Melizubaida Mahmud ${ }^{3}$ \\ Universitas Negeri Gorontalo, Gorontalo, Indonesia \\ israfanilogiswaralagili@gmail.com
}

\begin{abstract}
This research aims to identification of factors that influence the motivation of student learning on the study program S1 Economic Education, batch of 2015,Faculty of Economics, State University of Gorontalo. By Knowing the factors that influence the motivation to learn can provide useful information in teaching and learning process. The date in this study was obtained by distributing questionnaires to students of Economics Education, batch of 2015 Faculty of Economics, State University of Gorontalo, therefore, the data of this research are primary data.

The analytical teachnique used is Factor Analysis. The result of factor analysis shows that the most influential aspect toward student's learning motivation is physiology of $93,4 \%$. The next factor that influences is the desire to gain recognition/recognition $87,2 \%$, and social relationships with friends $80,6 \%$. While the lowest aspect that affesct the student's learning motivation sense of security in learning $75,8 \%$ and the desire to self-actualization by $75 \%$.
\end{abstract}

\section{ARTICLE HISTORY}

Received 1 Oktober 2018

Accepted 9 Desember 2018

\section{KEYWORDS}

Learning Motivation, College student, Economic Education, Gorontalo

\section{Pendahuluan}

Motivasi belajar mahasiswa dapat dilihat dari observasi tingkah laku yang dilakukan selama belajar dan dilihat dari hasil dari motivasi yang ditunjukkan dengan indeks prestasi kumulatif. Tingkah laku yang dapat diamati diantaranya adanya minat dan perhatian yang tinggi dalam kegiatan pembelajaran. Mahasiswa yang bekerja keras dan meluangkan waktu untuk belajar merupakan salah satu bentuk motivasi positif. Selain itu, adanya keinginan mahasiswa untuk terus bekerja sampai tugas terselesaikan adalah salah satu ciri tingkah laku yang positif dalam belajar serta yang menjadi hasil motivasi adalah indeks prestasi kumulatif dimana indeks prestasi kumulatif sebagai salah satu ukuran kemampuan mahasiswa dalam mengikuti kuliah. Sebagian besar mahasiswa yang memiliki motivasi dan kemampuan

Jambura : Economic Education Journal,Volume. 1, Issue. 1 January 2019. 
yang tinggi akan menghasilkan indeks prestasi kumulatif yang tinggi pula. Namun ada pula sebagian mahasiswa yang memiliki motivasi tinggi tetapi tidak didukung dengan kemampuan yang tinggi atau sebalikanya memiliki kemampuan yang tinggi namun tidak didukung motivasi yang kuat, sehingga menyebabkan mahasiswa tersebut memperoleh indeks prestasi kumulatif yang rendah.

Menurut Uno (2008:27), peran penting dari motivasi dalam belajar akan dapat menentukan penguatan belajar, memperjelas tujuan belajar, dan menentukan ketekunan belajar. Misalnya jika mahasiswa mengalami suatu hambatan dalam belajar maka seseorang tersebut akan mencari cara maupun alat yang akan membantu memecahkan masalahnya. Motivasi belajar akan memperjelas tujuan pembelajaran yang dilakukan apabila mahasiswa memahami manfaatnya. Mahasiswa yang memiliki motivasi yang tinggi akan memiliki keajegan dan ketekunan belajar untuk dapat mencapai harapan hasil yang baik. Menurut penelitian yang sudah dilakukan, menunjukkan bahwa motivasi belajar memiliki peranan yang signifikan dalam meningkatkan prestasi belajar. Mahasiswa yang memiliki motivasi belajar yang tinggi akan mencurahkan seluruh perhatiannya pada pembelajaran yang sedang dilaksanakannya. Namun pada kenyataannya, mahasiswa acap kali hanya bersemangat mengikuti pembelajaran di awal saja, setelah beberapa saat pembelajaran konsentrasi mahasiswa akan menurun dan perhatian mereka sudah tidak fokus lagi dan cenderung melakukan hal-hal di luar kegiatan pembelajaran.

Hasil observasi awal yang dilakukan oleh peneliti di Fakultas Ekonomi Khususnya di Program Studi Pendidikan Ekonomi Angkatan 2015 peneliti mendapatkan masalah yaitu rendahnya motivasi belajar hal ini dibuktikan masih banyak mahasiswa yang tidak aktif dalam pembelajaran, bermainmain handphone (sms, bermain game, chatting di sosial media ) ketika dosen menjelaskan, tidak fokus dalam memperhatikan, mahasiswa yang senang berada di kantin ketika proses pembelajaran berlangsung, ketika mendapat tugas dari dosen masih terdapat mahasiswa yang mengerjakan tugas secara mendadak dan itupun mengandalkan pekerjaan teman serta mengandalkan via internet, adanya mahasiswa yang tidak memiliki hubungan emosional yang baik dengan dosen disaat proses belajar mengajar, mahasiswa malas kuliah karena sibuk berorganisasi atau mengikuti kegiatan ekstrakurikuler pada saat jam perkuliahan, kondisi ekonomi orang tua (keadaan sosial ekonomi keluarga yang baik dapat menciptakan kondisi mahasiswa yang menghambat dalam belajar, mahasiswa berpikir bahwa untuk apa belajar dengan sungguh-sungguh/rajin jika orangtua mampu memenuhi dan memfasilitasi kebutuhan) serta kondisi orang tua yang tidak mampu juga akan menghambat motivasi belajar mahasiswa. Hal ini mengindikasikan bahwa motivasi belajar mahasiswa Program Studi Pendidikan Ekonomi Fakultas Ekonomi Universitas Negeri Gorontalo belum optimal.

\section{Kajian Teori}

\section{Motivasi Belajar}

Motivasi belajar mahasiswa adalah keseluruhan daya penggerak di dalam diri mahasiswa yang menimbulkan kegiatan belajar/proses perkuliahan yang menjamin kelangsungan dan yang memberikan arah pada kegiatan belajar, sehingga tujuan yang 
dikehendaki oleh subjek belajar itu dapat tercapai. Motivasi memegang peranan yang sangat penting dalam kegiatan belajar di perguruan tinggi, dan motivasi dipengaruhi oleh tujuan yang akan dicapai dengan belajar. Makin tinggi tujuan belajar maka akan semakin besar pula motivasinya, dan semakin besar motivasi belajarnya akan semakin kuat pula kegiatan belajarnya.

Kemampuan motivasi adalah kemampuan untuk memberikan semangat kepada diri sendiri guna melakukan sesuatu yang baik dan bermanfaat. Dalam hal ini terkandung adanya unsur harapan dan optimisme yang tinggi, sehingga memiliki kekuatan semangat untuk melakukan sesuatu aktifitas tertentu, misalnya dalam hal belajar. Itulah yang disebut dengan motivasi belajar (Asian Brain, 2008: halaman 1).

\section{Jenis-jenis Motivasi}

Menurut Syaiful Bahri (2000: 149-152), motivasi dapat dibedakan menjadi dua, yaitu motivasi dalam diri pribadi sesorang atau motivasi intrinsik dan motivasi yang berasal dari luar seseorang atau motivasi ekstrinsik. Adapun pengertian motivasi instrinsik dan ekstrinsik yaitu ;

\section{Motivasi Instrinsik}

Motivasi instrinsik merupakan dorongan kuat yang berasal dari dalam diri seseorang. Motivasi instrinsik sangat diperlukan untuk menumbuhkan motivasi belajar, peserta didik yang memiliki motivasi instrinsik selalu ingin maju dalam belajar, keinginan untuk ini dilatarbelakangi oleh pemikiran positfi bahwa semua pelajaran yang dipelajari sekarang akan berguna untuk dirinya baik untuk sekarang maupun dimasa yang akan datang.

Motivasi Ekstrinsik
Motivasi ekstrinsik adalah keinginan untuk mencapai sesuatu didorong karena ingin mendapatkan penghargaan eksternal atau menghindari hukuman eksternal. Seorang anak dikatakan memiliki motivasi ekstrinsik untuk belajar jika peserta didik menempatkan tujuan belajarnya di luar hal yang dipelajarinya, misalnya untuk mencapai angka tinggi, gelar, dan kehormatan. Contoh motivasi yang diberikan biasanya dapat berupa pujian kepada peserta didik, hadiah, angka, dan sebagainya yang berpengaruh untuk merangsang mahasiswa untuk giat belajar.

Faktor-faktor yang Mempengaruhi Motivasi Faktor Internal

\section{Cita-cita dan Aspirasi}

Cita-cita merupakan faktor yang dapat memberikan semangat serta memberikan tujuan yang jelas dalam belajar. Aspirasi merupakan harapan seseorang akan suatu keberhasilan atau prestasi tertentu. 2.) Kemampuan peserta didik, Kemampuan peserta didik merupakan segala potensi intelektual (kemampuan problem solving), kognitif, motorik, verbal, dan sikap. Kondisi peserta didik. 3) Kesehatan jasmani dan rohani yang sehat akan mendorong pemusatan perhatian dan gairah dalam belajar. 4.) Unsurunsur dinamis dalam pembelajaran. Unsurunsur dinamis meliputi perasaan, perhatian, ingatan, kemauan, dan pengalaman hidup.

\section{Faktor Eksternal}

\section{Kondisi lingkungan belajar}

Kondisi lingkungan belajar yang kondusif meliputi lingkungan sosial dan lingkungan non sosial. 2.) Upaya pengajar dalam mengajarkan peserta didik. Pengajar adalah salah satu faktor yang memiliki peran besar dalam memotivasi seseorang untuk belajar, diantaranya dengan kualitas dosen, materi 
perkuliahan, serta metode perkuliahan. Kualitas dosen merupakan kompetensi, kematangan, serta jenjang dosen pengampu mata kuliah.

Faktor-faktor Penyebab Rendahnya Motivasi Belajar

\section{Orang tua}

Menurut Skinner bahwa motivasi sangat ditentukan oleh lingkungannya. Lingkungan yang pertama dan utama yang mempengaruhi motivasi anak adalah lingkungan keluarga.

Suteja (1995) menjelaskan bahwa orang tua yang selalu menuntut anak untuk berprestasi tinggi tanpa memperhatikan kemampuannya dapat mengakibatkan anakanak kehilangan kesukaannya terhadap belajar. Begitu juga dengan sikap orang tua yang masa bodoh terhadap pendidikan anaknya juga dapat mengakibatkan rendahnya motivasi anak dalam belajar.

Kurangnya perhatian orang tua terhadap anaknya, seperti sikap orang tua yang terlalu sibuk dengan pekerjaannya atau orang lain dapat menyebabkan turunnya motivasi belajar anak. Sebaliknya Gottman (1998) dalam sebuah penelitiannya mengungkapan bahwa anak-anak yang merasa dihormati dan dihargai dalam keluargakeluarga mereka lebih berhasil di sekolah, mempunyai lebih banyak sahabat dan menempuh kehidupan yang lebih sehat dan sukses.

\section{Guru}

Kurangnya kompetensi yang dimiliki guru dalam mengajar dapat mempengaruhi motivasi belajar siswa. Guru harus mampu mengatasi kesulitan belajar yang dialami siswanya. Karena, jika kesulitan belajar tidak ditangani oleh guru akan menyebabkan siswa tersebut ketinggalan materi pelajaran.
Hal ini akan menyebabkan turunnya motivasi belajar siswa untuk mempelajari materi selanjutnya.

\section{Kondisi Sosial Ekonomi}

Aspek kondisi ekonomi sosial sangat berpengaruh terhadap motivasi belajar anak karena anak yang sedang belajar selain harus dipenuhi kebutuhan pokoknya. Misalnya makanan, pakaian, perumahan, kesehatan, dan lain-lain, juga membutuhkan fasilitas belajar seperti ruang belajar, meja, kursi, penerangan, alat tulis menulis, buku-buku, dan lain sebagainya. Adanya fasilitas belajar tersebut, memungkinkan anak untuk belajar dengan baik. Namun semua kebutuhan akan fasilitas belajar baru terpenuhi dengan baik bila ekonomi keluarga memadai. Untuk belajar, anak memerlukan sarana dan prasarana yang dibutuhkan, misalnya membayar uang SPP, alat tulis menulis, pakaian sekolah, buku-buku literature, uang transportasi dan lain-lainya demikian pula ketenangan, keamanan, kesehatan baik jasmani maupun rohani. Bagi keluarga yang pendapatanya rendah tentunya sulit baginya untuk menyediakan sarana belajar minimal harus dipenuhi dengan baik. Mungkin tempat belajarnya ada tidak memenuhi persyaratan hanya merupakan tempat belajar yang sederhana. Anies (1979 : 37 ) mengemukakan tentang pendapat dan tempat belajar yaitu : Kemerosotan belajar di Sekolah atau kesulitan belajar dipengaruhi pula oleh kemerosotan sosial ekonomi orang tua, ada tidaknya tempat belajar sendiri, banyaknya anggota keluarga yang tinggal dalam satu rumah dan fasilitas-fasilitas lainya. Juga demikian secara psikologi akan menimbulkan kekecewaan. Anak menjadi kecewa karena memerlukan peralatan belajar tetapi tidak terpenuhi, akhirnya semangat untuk belajar yang 
tadinya besar dapat menurun kembali. Tetapi kadangkala terjadi pada anak ketika orang tua mampu memenuhi dan memfasilitasi kebutuhan atau fasilitas, anak akan berpikir untuk apa belajar dengan sungguhsungguh/rajin jika orangtua mampu memenuhi semua kebutuhan maka hal ini akan menghambat dan mengurangi tingkat motivasi belajar anak.

\section{Teknologi dan Media Sosial}

Seiring berkembangnya zaman, teknologi semakin hari semakin canggih serta adanya internet dan banyaknya media sosial yang memudahkan untuk mendapatkan informasi dan berkomunikasi. Tidak dapat dipungkiri hal tersebut memberikan dampak langsung maupun tidak langsung bagi masyarakat baik dampak positif maupun negatif. Situs media social di internet bermacam-macam jenis dan bentuknya misalnya : facebook, twitter, instagram, path dan sebagainya. Adanya internet dan media sosial sebagian besar dimanfaatkan oleh remaja bahkan anak dibawah umur memiliki akun media sosial. Sehingga adanya media sosial memberikan pengaruh dalam dunia pendidikan. Dampak buruk yang mungkin terjadi adalah menurunnya motivasi belajar siswa, dimana motivasi merupakan hal yang penting untuk menentukan hasil belajar siswa. Menghabiskan waktu hanya untuk selalu aktif di media social sudah jelas mengurangi waktu belajar atau bahkan menghilangkan waktu belajar. Sehingga mereka hanya termotivasi untuk menjadi "hits" bukan menjadi pelajar yang pintar. Penggunaan media social harusnya dimanfaatkan sebaik mungkin, bukan berarti tidak boleh aktif di media social namun harus diingat kewajiban sebagai seorang pelajar yaitu belajar. Jadikanlah media social hanya sebagai selingan di waktu senggang, bukan sebagai prioritas, sehingga pendidikan dan dunia social dapat berjalan dengan seimbang Organisasi

Organisasi merupakan suatu wadah untuk menyalurkan serta mengembangkan minat dan bakat mahasiswa. Dengan mengikuti organisasi mahasiswa bisa menambah wawasan, mendapat banyak teman yang bisa memacu semangat belajar mereka dan mempunyai jaringan yang lebih luas dibandingkan dengan mahasiswa yang tidak ikut organisasi. Ada terdapat faktor positif dan negatif dalam mengikuti organisasi dan semua tergantung dari mahasiswa itu sendiri. Faktor positifnya seperti yang sudah dijelaskan diatas kemudian faktor negatifnya adalah jika mahasiswa sulit membagi waktu antara organisasi dengan perkuliahan maka hal yang akan terjadi rendahnya IPK atau Indeks Prestasi Kumulatif. Tetapi jika mahasiswa mampu membagi waktu maka yang terjadi prestasi yang gemilang.

\section{Jenis Kelamin}

Aulia (2012) mengungkapkan bahwa beberapa penelitian menunjukkan terdapat perbedaan motivasi antara laki-laki dan perempuan dalam hal pencapaian prestasi yang lebih tinggi. Siswa laki-laki memiliki motivasi yang lebih tinggi dari pada siswa permpuan dalam hal untuk berprestasi dalam belajar. Rendahnya motivasi yang dimiliki siswa perempuan disebabkan karena bertentangan dengan nilai-nilai tradisional yang ada pada masyarakat.

Aspek Psikis

Dimyati dan Mudjiono mengemukakan bahwa tinggi rendahnya motivasi dapat dipengaruhi oleh aspek psikis yang ada pada diri siswa, misalnya penga- 
matan, perhatian, ingatan, daya pikir, dan fantasi.

\section{Prinsip-prinsip Motivasi}

Kenneth H. Hover (dalam Hamalik 2006 : 163-166) mengemukakan prinsipprinsip motivasi sebagai berikut : 1). Pujian lebih efektif dari pada hukuman; 2). Semua murid mempunyai kebutuhan-kebutuhan psikologis (yang bersifat dasar) tertentu yang harus mendapat kepuasan; 3). Motivasi yang berasal dari dalam indvidu lebih efektif dari pada motivasi yang dipaksakan dari luar; 4). Terhadap jawaban (perbuatan) yang serasi (sesuai dengan keinginan) perlu dilakukan usaha pemantauan; 5). Motivasi mudah menjalar atau tersebar terhadap orang lain; 6). Pemahaman yang jelas terhadap tujuantujuan akan merangsang motivasi; 7). Tugastugas di bebankan oleh diri sendiri akan menimbulkan minat yang lebih besar untyk mengerjakannya dari pada apabila tugastugas itu di paksakan oleh guru: 8). Pujianpujian yang datang dari luar kadang-kadang di perlukan dan cukup efektif merangsang minat yang sebenarnya; 9). Teknik dan proses mengajar yang bermacam-macam adalah efektif untuk memelihara minat murid; 10). Manfaat minat yang telah dimiliki oleh murid adalah bersifat ekonomis; 11). Kegiatan-kegiatan yang akan dapat merangsang minat murid-murid yang kurang mungkin tidak ada artinya bagi para mahasiswa yang tergolong pandai; 12). Kecemasan yang besar akan menimbulkan kseulitan belajar; 13). Kecemasan dan frustasi yang lemah dapat membantu belajar, dapat juga lebih baik; 14). Apabila tugas tidak terlalu sukar dan apabila tidak ada maka frustasi secara cepat menuju ke demoralisasi; 15). Setiap murid mempunyai tingkat-tingkat frustasi toleransi yang berlainan; 16).
Tekanan kelopok murid kebanyakan lebih efektif dalam motivasi dari pada tekanan/paksaan dari orang dewasa; 17). Motivasi yang besar hubungannya dengan kreatifitas murid.

\section{Peran dan Fungsi Motivasi serta Teori-teori} Motivasi dalam Belajar

Peran Motivasi dalam Belajar

Ada beberapa peran penting dari motivasi dalam belajar dan pembelajaran, antara lain adalah : a.) Menentukan penguatan belajar, b.) Memperjelas tujuan belajar, c.) Menentukan ketekunan belajar.

\section{Fungsi Motivasi}

a.) Mendorong manusia untuk berbuat sesuatu Motivasi sebagai penggerak atau motor yang melepaskan energi. Motivasi dalam hal ini merupakan motor penggerak dan setiap kegiatan yang akan dikerjakan

b.) Menentukan arah perbuatan seseorang

Motivasi menentukan kearah tujuan yang hendak dicapai. Dengan demikian motivasi dapat memberikan arah dan kegiatan yang harus dikerjakan sesuai dengan rumusan tujuannya.

c.) Menyeleksi perbuatan

Yakni menentukan perbuatan-perbuatan apa yang harus dikerjakan, yang sesuai guna mencapai tujuan, dengan menyisihkan perbuatanperbuatan yang tidak bermanfaat bagi tujuan tersebut.

\section{Teori Motivasi}

\section{Teori Hierarki Maslow}

Teori Hierarki ini dikemukakan oleh seorang psikolog yang bernama Abraham Maslow pada tahun 1943. Teori ini mengemukakan 5 kebutuhan hidup manusia berdasarkan hirarkinya yaitu mulai dari kebutuhan yang mendasar hingga kebutuhan yang lebih tinggi. Teori ini kemudian dikenal dengan Teori Maslow atau Teori Hirarki. 
Kebutuhan hirarki kelima kebutuhan tersebut diantaranya adalah : a). Kebutuhan sosiologis (Physiological needs), yaitu kebutuhan terhadap makanan, minuman, air, udara, pakaian, tempat tinggal dan kebutuhan untuk bertahan hidup. Kebutuhan Fisiologis merupakan kebutuhan yang paling mendasar; b). Kebutuhan Keamanan (Safety needs), yaitu kebutuhan akan rasa aman dari kekerasan baik fisik maupun psikis seperti lingkungan yang aman bebas polusi, perlindungan keselamatan dan kesehatan kerja serta bebas dari ancaman; c). Kebutuhan Sosial (Social needs), yaitu kebutuhan untuk dicintai dan mencintai. Manusia merupakan makhluk sosial, Setiap orang yang hidup di dunia memerlukan keluarga dan teman; d). Kebutuhan Penghargaan (Esteem needs), Maslow mengemukan bahwa setelah memenuhi kebutuhan Fisiologis, Keamanan dan Sosial, orang tersebut berharap diakui oleh orang lain, memiliki reputasi dan percaya diri serta dihargai oleh setiap orang; e). Kebutuhan Aktualisasi diri(Self-Actualization), Kebutuhan ini merupakan kebutuhan tertinggi menurut Maslow, Kebutuhan Aktualisasi diri adalah kebutuhan atau keinginan seseorang untuk memenuhi ambisi pribadinya.

Indikator Motivasi Belajar

Menurut Sardiman (2011:83), seseorang yang termotivasi dalam belajar memiliki ciri- ciri sebagai berikut: 1). Tekun menghadapi tugas, yakni mengerjakan terus menerus dalam waktu yang lama dan tidak akan berhenti sebelum selesai; 2). Ulet menghadapi kesulitan, yakni tidak mudah berputus asa dalam mengerjakan tugas untuk berprestasi sebaik mungkin; 3). Ingin mendalami bahan atau bidang pengetahuan yang diberikan; 4). Selalu berusaha berprestasi sebaik mungkin; 5). Menunjukkan minat terhadap berbagai problematika kehidupan orang dewasa; 6). Senang, rajin, penuh semangat serta cepat bosan dengan tugas-tugas rutin; 7). Dapat mempertahankan pendapatnya; 8). Mengerjakan tugas dalam jangka waktu panjang; 9). Senang untuk mencari dan memecahkan masalah: 10). Tidak memerlukan dorongan dari luar untuk berprestasi

\section{Metodologi Penelitian}

Pengujian data dimulai dari Uji Validitas, Uji reliabilitas Analisis Deskriptif Variabel Penelitian (Analisis Jawaban responden), dan hipotesis. Pengujian hipotesis bertujuan menguji ada tidaknya pengaruh motivasi belajar mahasiswa Program Studi Pendidikan Ekonomi Angkatan 2015. Hipotesis penelitian diuji dengan menggunakan Analisis Faktor.

\section{Hasil Penelitian}

Pengujian Instrumen Penelitian

Hasil Pengujian Validitas dan Reliabilitas: 


\begin{tabular}{|c|c|c|c|c|}
\hline Dimensi & Pertanyaan & Nilai $r$ & r patokan & Keterangan \\
\hline \multirow{9}{*}{ Fisiologis } & M1 & 0.484 & \multirow{9}{*}{0.3} & Valid \\
\hline & M2 & 0.310 & & Valid \\
\hline & M3 & 0.613 & & Valid \\
\hline & M4 & 0.519 & & Valid \\
\hline & M5 & 0.322 & & Valid \\
\hline & M6 & 0.365 & & Valid \\
\hline & M7 & 0.593 & & Valid \\
\hline & M8 & 0.322 & & Valid \\
\hline & M9 & 0.486 & & Valid \\
\hline \multirow{8}{*}{ Rasa Aman } & M10 & 0.349 & \multirow{8}{*}{0.3} & Valid \\
\hline & M11 & 0.547 & & Valid \\
\hline & M12 & 0.404 & & Valid \\
\hline & M13 & 0.565 & & Valid \\
\hline & M14 & 0.588 & & Valid \\
\hline & M15 & 0.566 & & Valid \\
\hline & M16 & 0.314 & & Valid \\
\hline & M17 & 0.657 & & Valid \\
\hline \multirow{3}{*}{ Hubungan Sosial } & M18 & 0.640 & \multirow{3}{*}{0.3} & Valid \\
\hline & M19 & 0.597 & & Valid \\
\hline & M20 & 0.466 & & Valid \\
\hline \multirow{4}{*}{ Penghargaan } & M21 & 0.703 & \multirow{4}{*}{0.3} & Valid \\
\hline & M22 & 0.685 & & Valid \\
\hline & M23 & 0.715 & & Valid \\
\hline & M24 & 0.546 & & Valid \\
\hline \multirow{9}{*}{ Aktualisasi Diri } & M25 & 0.555 & \multirow{9}{*}{0.3} & Valid \\
\hline & M26 & 0.536 & & Valid \\
\hline & M27 & 0.668 & & Valid \\
\hline & M28 & 0.367 & & Valid \\
\hline & M29 & 0.593 & & Valid \\
\hline & M30 & 0.598 & & Valid \\
\hline & M31 & 0.326 & & Valid \\
\hline & M32 & 0.700 & & Valid \\
\hline & M33 & 0.704 & & Valid \\
\hline \multicolumn{2}{|c|}{$\begin{array}{l}\text { Koefisien Reliabilitas Alpha } \\
\text { Cronbach's }\end{array}$} & 0.912 & 0.6 & Reliabel \\
\hline
\end{tabular}


Berdasarkan hasil analisis diatas terlihat bahwa seluruh pertanyaan yang digunakan telah memiliki nilai koefisien korelasi diatas 0,3 . Dengan demikian seluruh pertanyaan tersebut telah memenuhi syarat validitas. Demikian pula untuk koefisien alpha cronbach yang sebesar 0,912 diatas menunjukkan seluruh pertanyaan yang digunakan telah memberikan hasil pengukuran yang konsisten.

\section{Analisis Faktor}

Analisis faktor merupakan prosedur statistik untuk mereduksi atau meringkas data, dari sejumlah variabel-variabel yang saling independen satu dengan yang lain sehingga bisa dibuat satu atau beberapa kumpulan variabel yang lebih sedikit dari jumlah variabel awal, yang disebut sebagai faktor dan masih memuat sebagian besar informasi yang terkandung dalam variabel awal. Di dalam analisis faktor, variabelvariabel awal tidak dikelompokkan menjadi variabel bebas dan tidak bebas, sebaliknya sebagai penggantinya seluruh set hubungan interdependen antar variabel tersebut diteliti. Dalam penelitian ini, variabel-variabel yang dimaksudkan penjelasan di atas adalah faktor-faktor yang mempengaruhi motivasi belajar mahasiswa pada Program Studi S1 Pendidikan Ekonomi Angkatan 2015.

Penilaian Kelayakan Variabel
Langkah pertama dalam analisis faktor adalah menilai variabel mana saja yang layak untuk dimasukkan dalam analisis selanjutnya. Pengujian ini dilakukan dengan memasukkan semua variabel yang ada, kemudian pada variabel-variabel tersebut dikenakan sejumlah pengujian

Pengujian-pengujian yang dikenakan terhadap variabel tersebut diantaranya pengujian Bartlett Test's dan Kaiser-Meyer-Olkin Measure of Sampling Aquadecy (KSO MSA).

Pengujian Bartlett Test's berfungsi untuk menguji apakah sampel (variabel) yang diamati sudah memadai untuk dianalisis lebih lanjut atau tidak. Sedangkan MSA berfungsi untuk melihat apakh suatu variabel layak untuk dianalisis atau tidak. Nilai MSA berkisar antara 0 sampai 1 .

1. MSA =1, variabel tersebut dapat diprediksi tanpa kesalahan oleh variabel yang lain.

2. MSA $>0.5$, variabel masih bisa diprediksi dan bisa dianalisis lebih lanjut.

3. MSA $<0.5$, variabel tidak bisa diprediksi dan tidak bisa dianalisis lebih lanjut, atau dikeluarkan dari variabel lainnya.

4. Pengujian dilakukan berulang kali sampai didapat nilai MSA yang lebih besar dari 0.5 dari tiap-tiap variabel yang diamati.

Hasil pengujian kelayakan variabel-variabel yang diamati adalah sebagai berikut :

KMO and Bartlett Test

KMO and Bartlett's Test

\begin{tabular}{llr}
\hline \hline Kaiser-Meyer-Olkin Measure of Sampling Adequacy. & .712 \\
Bartlett's Test of & Approx. Chi-Square & 57.968 \\
Sphericity & df & 10 \\
& Sig. & .000 \\
\hline \hline
\end{tabular}

Sumber : SPSS 13.0 
Indeks KMO measure of sampling adequacy yang tinggi sebesar 0,712>0.5 menunjukkan bahwa analisis faktor yang digunakan sudah sesuai. Artinya semua faktor/variabel yang diamati telah memenuhi syarat untuk dapat dianalisis lebih lanjut. Sedangkan untuk uji Bartlett, hipotesisnya adalah:

$\mathrm{H}_{0} \quad$ = variabel-variabel saling berkorelasi dalam populasi (matriks korelasi populasi bukan merupakan matriks identitas)

$\mathrm{H}_{1}$ = variabel-variabel tidak saling berkorelasi dalam populasi (matriks korelasi populasi merupakan matriks identitas)

$\alpha=0,05$

Kriteria pengujian: $\mathrm{H}_{0}$ ditolak jika nilaisignifikansi yang diperoleh lebih kecil dari nilai alpha yang digunakan $(0,05)$, diterima dalam hal lainnya. Terlihat pada tabel di atas angka signifikansi. sebesar 0,000 (jauh di bawah $\alpha=0,05$ ), sehingga $\mathrm{H}_{0}$ ditolak. Berarti syarat interdependensi antar variabel telah dipenuhi.

\section{Hasil Analisis Faktor}

Setelah pengujian kelayakan seluruh variabel memberikan hasil yang layak maka selanjutnya dilakukan analisis terhadap 5 faktor yang diamati untuk mengetahui faktor mana yang memberikan pengaruh dalam menentukan motivasi belajar mahasiswa Program Studi S1 Pendidikan Ekonomi angkatan 2015. Untuk mengetahui berapa besar variasi yang dikontribusikan oleh masing-masing faktor dapat dilihat dari nilai Communalities masing-masing variabel/faktor tersebut. Nilai communalities dari seluruh faktor yang diamati disajikan dalam tabel berikut:

\begin{tabular}{|c|c|c|}
\hline \multicolumn{3}{|c|}{ Commonumalities: } \\
\hline & Initial & Extraction \\
\hline Fisiologis & 1.000 & 934 \\
\hline Fasa Aman & 1.000 & $.75 \theta$ \\
\hline Hubungan Sosial & 1.000 & .902 \\
\hline Penghargaan & 1.000 & 970 \\
\hline Altualisasi Diri & 1.000 & 747 \\
\hline
\end{tabular}

Sumber : SPSS 13.0

Besarnya nilai communality suatu variabel menyatakan tingkat variasi yang dapat dijelaskan oleh faktor yang ada. Jadi nilai communality untuk variabel fisiologis sebesar 0,934 mengandung arti sebesar 93,4\% varian motivasi belajar mahasiswa Program Studi Pendidikan Ekonomi Universitas Negeri Gorontalo angkatan 2015 ditentukan oleh variabel ini. Berangkat dari penjelasan tersebut, dapat diketahui secara umum variabel-variabel mana saja yang memberikan pengaruh paling besar terhadap motivasi belajar mahasiswa Program Studi Pendidikan Ekonomi Universitas Negeri Gorontalo angkatan 2015. Semakin besar nilai communality suatu variabel semakin besar pengaruh yang dikontribusikannya. Di bawah ini disajikan tabel yang memuat urutan variabelvariabel penelitian yang memberikan pengaruh terbesar hingga yang terkecil berdasarkan interpretasi nilai communality-nya. 
Urutan Variabel Penelitian berdasarkan Interprestasi Nilai Communality

\begin{tabular}{|c|l|l|}
\hline No & $\begin{array}{c}\text { Faktor Penentu Motivasi Belajar } \\
\text { Mahasiswa }\end{array}$ & Extraction \\
\hline 1 & Fisiologis & 0.9344 \\
\hline 2 & Penghargaan & 0.8702 \\
\hline 3 & Hubungan Sosial & 0.8016 \\
\hline 4 & Rasa Aman & 0.7581 \\
\hline 5 & Aktualisasi Diri & 0.7473 \\
\hline
\end{tabular}

Sumber : SPSS 13.0

Berdasarkan hasil di atas terlihat bahwa faktor yang paling dominan dalam menentukan motivasi belajar mahasiswa Program Studi Pendidikan Ekonomi Universitas Negeri Gorontalo angkatan 2015 adalah faktor fisiologis. Ini didasarkan nilai communality untuk variabel ini yang mencapai 0,9334 .

Faktor selanjutnya yang dominan dalam mempengaruhi motivasi belajar mahasiswa Program Studi Pendidikan Ekonomi Universitas Negeri Gorontalo angkatan 2015 adalah keinginan untuk memperoleh penghargaan/pengakuan $(0,8702)$, hubungan sosial yang terjalin dengan teman $(0,8016)$, rasa aman dalam belajar $(0,7581)$, serta keinginan untuk aktualisasi diri $(0,7473)$.

\section{Pembahasan}

Dalam kegiatan belajar mengajar peranan motivasi sangat diperlukan. Rendahnya motivasi belajar mahasiswa seringkali diduga menjadi penyebab rendahnya kualitas lulusan sebuah perguruan tinggi. Motivasi belajar mahasiswa adalah sebagai suatu keadaan dalam diri mahasiswa yang mendorong dan mengarahkan perilakunya pada tujuan yang ingin dicapainya dalam mengikuti pendidikan tinggi. Idealnya, tujuan mahasiswa dalam mengikuti pendidikan tinggi adalah untuk menguasai bidang ilmu yang dipelajarinya. Sehingga dalam mempelajari setiap bahan pembelajaran, mahasiswa terdorong untuk menguasai bahan pembelajaran tersebut dengan baik, dan bukan hanya untuk sekedar lulus meski dengan nilai yang sangat baik sekalipun.

Banyak faktor yang mempengaruhi motivasi belajar mahasiswa diantaranya kebutuhan akan fisik, keinginan untuk memperoleh rasa aman dalam belajar, kebutuhan akan hubungan sosial, keinginan untuk memperoleh penghargaan, serta kebutuhan untuk aktualisasi diri. Berdasarkan hasil analisis yang telah dilakukan diperoleh bahwa dari lima faktor yang diamati tersebut, faktor yang memiliki pengaruh terbesar terhadap motivasi belajar mahasiswa Program Studi Pendidikan Ekonomi Universitas Negeri Gorontalo Angkatan 2015 adalah faktor fisiologis atau kebutuhan fisik. Ini didasarkan pada nilai loading factor yang mencapai 0,9344.

Terpenuhinya kebutuhan fisik menjadi faktor utama seperti dilihat dalam tabel communality di atas untuk variabel kebutuhan fisik sebesar 0,9344. Jadi hal ini sangat mempengaruhi motivasi belajar mahasiswa karena kebutuhan fisik ini yang akan menjadi penentu mahasiswa menjadi 
semangat dalam belajar atau tidak. Kebutuhan-kebutuhan itu seperti kebutuhan akan makanan, minuman, tempat berteduh, tidur serta oksigen dan air. Kebutuhan-kebutuhan fisiologis adalah potensi paling dasar dan besar bagi semua pemenuhan kebutuhan di atasnya. Misalnya manusia yang lapar akan termotivasi untuk makan, bukan untuk mencari teman atau dihargai. Manusia akan mengabaikan atau menekan dulu semua kebutuhan lain sampai kebutuhan fisiologisnya itu terpuaskan. Jadi faktor kebutuhan fisik yang dimaksud antara lain kondisi fisik mahasiswa. Jika mahasiswa merasa lapar atau terlalu capek bahkan dalam kondisi kurang prima maka motivasi belajar juga akan menurun. Namun jika kondisi fisik mahasiswa dalam keadaan baik (terpenuhi kebutuhan fisiologis) maka mereka akan semangat dalam belajar. Demikian pula untuk kondisi sarana dan prasarana yang menunjang proses pembelajaran. Semakin baik kondisi fisik sarana dan prasarana yang ada maka akan meningkatkan motivasi mahasiswa dalam belajar. Misalnya ruangan kelas yang nyaman seperti disediakan kursi yang tidak rusak, papan tulis yang bagus, $\mathrm{AC} /$ kipas angin yang masih berfungsi, jendela sirkulasi, wifi, lcd projector, dan contoh lainya seperti satuan pengamanan kampus,kantin bersih dan sehat, toilet yang bersih dengan jumlah yang memadai, waktu isitrahat yang cukup untuk ke kamar kecil atau untuk minum, serta lingkungan belajar yang kondusif.

Faktor selanjutnya yang memiliki pengaruh terbesar terhadap motivasi belajar mahasiswa adalah keinginan untuk memperoleh penghargaan sebesar 0,8702 dan hubungan sosial yang terjalin antara rekanrekan mahasiswa sebesar 0,8016. Keinginan untuk dihargai menjadi faktor pendorong mahasiswa untuk termotivasi dalam belajar karena bila memperoleh prestasi yang baik maka mahasiswa akan mendapat apresiasi maupun pujian dari rekan atau dosen. Misalnya dalam aplikasinya dipenuhi dengan cara: a). Self-Estem (membangun rasa percaya diri mahasiswa), seperti mengembangkan pengetahuan baru berdasarkan latar belakang pengetahuan untuk membantu memastikan keberhasilan (scaffolding); mengembangkan system pembelajaran, yang sesuai dengan kebutuhan mahasiswa; fokus pada kekuatan dan asset mahasiswa; mengembangkan metode pembelajaran yang beragam; mempertimbangkan kebutuhan dan kemampuan mahasiswa ketika merencanakan dan melaksanakan pembelajaran; mengembangkan dan memberikan contoh strategi belajar pada mahasiswa; tidak menegur mahasiswa di depan umum; memberikan bantuan pada mahasiswa yang mengalami kesulitan; melibatkan mahasiswa untuk berpartisipasi dan bertanggung jawab di kelas; b). Penghargaan dari pihak lain dengan cara: mengembangkan iklim kelas dan pembelajaran kooperatif di mana setiap mahasiswa dapat saling menghormati dan mempercayai, tidak saling mencemoohkan; menyelenggarakan pemilihan ketua senat/ Badan Eksekutif Mahasiswa secara terbuka; mengembangkan program penghargaan atas pekerjaan, usaha dan prestasi yang diperoleh mahasiswa; mengembangkan kurikulum yang dapat mengantarkan setiap mahasiswa untuk memiliki sikap empatik dan menjadi pendengar yang baik; berusaha melibatkan para mahasiswa dalam setiap pengambilan keputusan yang terkait dengan kepentingan para mahasiswa itu sendiri; c). Pengetahuan dan pemahaman seperti : memberikan kesem- 
patan kepada para mahasiswa untuk mengeksplorasi bidang-bidang yang ingin diketahunya; menyedeiakan model pembelajaran yang memberikan tantangan inteletual melalui pendekatan discovery-incuiry; menyediakan topik-topik pembelajaran dengan sudut pandang yang beragam; memberikan kesempatan kepada mahasiswa untuk berpikir filosofis dan berdiskusi; d). Aesthetic (Estetik), berupa : menata ruangan kelas secara rapi dan menarik; memleihara sarana dan prasarana yang ada di sekeliling kampus, ruangan yang bersih dan wangi, tersedia taman kampus, dan kampus yang tertata indah.

Demikian pula dengan hubungan sosial yang terjalin dengan sesama dosen maupun mahasiswa. Semakin baik hubungan sosial maka akan semakin meningkatkan motivasi belajar. Karena hubungan sosial yang baik akan dapat meningkatkan keinginan untuk saling membantu dalam proses belajar. Misalnya dalam hubungan antara dosen dan mahasiswa, hendaknya: bersikap empatik, perhatian dan interest kepada mahasiswa, sabar, adil, mau membuka diri, positif, dan dapat menjadi pendengar yang baik; memahami mahasiswa (kebutuhan, potensi, minat, karakteristik balik yang positif dari pada yang negatif; menghargai dan menghormati setiap pemikiran, pendapat dan keputusan mahasiswa; menjadi penolong yang bias diandalkan dan memberikan kepercayaan terhadap mahasiswa. Kemudian hubungan antara mahasiswa dengan mahasiswa dapat dilakukan dengan cara: mengembangkan situasi yang memungkinkan terciptanya kerja sama mutualistik dan saling percaya di antara mahasiswa; mengembangkan diskusi kelas; peer tutoring; mengembangkan Unit
Kegiatan Mahasiswa (UKM), humpunan mahasiswa jurusan, dan kegiataan kemahasiswaan lainya.

Adapun untuk faktor rasa aman dalam belajar sebesar 0,7581 dan keinginan untuk beraktualisasi diri sebesar 0,7473. Keinginan untuk memperoleh rasa aman menjadi faktor pendorong mahasiswa untuk termotivasi dalam belajar karena rasa aman juga tidak hanya dilihat dalam arti keamanan fisik melainkan bersifat psikologis seperti perlakuan manusiawi dan adil. Jadi untuk kebutuhan rasa aman mahasiswa ini dapat dipenuhi dengan cara: mempersiapkan pembelajaran dengan baik (materi kuliah, media pembelajaran); sikap dosen yang menyenangkan, tidak menghakimi, dan tidak mengancam, mengendalikan perilaku mahasiswa di kelas, menegakkan disiplin dengan adil, consistent expectations, lebih banyak memberikan penguatan perilaku (reinforcement) melalui pujian/ganjaran atas segala perilaku positif mahasiswa daripada pemberian hukuman atas perilaku negatif. Kemudian untuk aktualisasi diri menjadi faktor yang berpengaruh paling rendah pada motivasi belajar mahasiswa Pendidikan Ekonomi Angkatan 2015 dikibatkan karena kebanyakan mahasiswa tidak mau berkeinginan untuk menggali dan menjelajah kemampuan dan potensi yang dimilikinya.

\section{Kesimpulan}

Berdasarkan hasil analisis yang telah dilakukan maka dapat diambil beberapa kesimpulan sebagai berikut : 1). Faktor yang berpengaruh paling dominan terhadap motivasi belajar mahasiswa Program Studi Pendidikan Ekonomi Fakultas Ekonomi Universitas Negeri Gorontalo angkatan 2015 secara berturut-turut adalah faktor fisiologis atau kebutuhan fisik: 2). Adapun faktor yang 
mempunyai pengaruh relatif rendah terhadap motivasi belajar mahasiswa adalah keinginan untuk mengaktualisasi diri.

Saran

Berdasarkan kesimpulan di atas maka penulis memberikan saran sebagai berikut : 1). Untuk meningkatkan motivasi belajar mahasiswa, pihak Program Studi Pendidikan Ekonomi sebaiknya memperhatikan kondisi fisik dari sarana prasarana belajar; 2). Sebaiknya bagi mahasiswa yang berprestasi diberikan hadiah atas prestasi yang telah berhasil dicapai; 3). Untuk penelitian selanjutnya sebaiknya mengamati faktorfaktor lain yang berpengaruh terhadap motivasi belajar mahasiswa seperti harapan, dukungan orang tua, dll.

\section{Daftar Pustaka}

Agata, Kurnia Andika. 2016. Gambaran FaktorFaktor yang Mempengaruhi Motivasi Belajar Mahasiswa Program Studi Ilmu Keperawatan Universitas Diponegoro Semarang.Skripsi.Universitas Diponegoro Semarang.

Ahmadi, Abu 1993. Cara Belajar Mandiri dan Sukses. Solo: CV Aneka Cipta.

A.M. Sudirman, 2006. Interaksi dan Motivasi Belajar Mengajar, Jakarta : PT Raja Grafindo Persada

Arikunto, S. 2012. Prosedur Penelitian, Suatu Pendekatan Praktek. Jakarta: Rineka Cipta

Asian.Brain. 2008, Motivasi belajar sistem, www.anneahira.com./motivasi.index.htm. 15 Februari 2017. 18.45 WITA

Asih, 2015. Motivasi Belajar Siswa di SMP Negeri 15 Yogyakarta.Skripsi.Universitas Negeri Yogyakarta

Dakio, Putri Vindi. 2016. Pengaruh Situs Jejaring Sosial Facebook Terhadap Motivasi Belajar Mahasiswa Jurusan Pendidikan Ekonomi Angkatan 2014 Fakultas Ekonomi Universitas Ngeri Gorontalo. Skripsi. Universitas Negeri Gorontalo
Dimyati dan Mudjiono, 2006. Belajar dan Pembelajaran. Jakarta; PT Rineka Cipta

Hamalik, Oemar 2002. Psikologi Belajar dan Mengajar. Bandung : Sinar Baru Algensindo.

Kasmilah, 2010. Faktor-faktor yang Mempengaruhi Motivasi Mahasiswa Untuk Berprestasi dalam Mengikuti Mata Kuliah Keperawatan Anak Studi Kasus di Akedemi Keperawatan Pragolopati Pati.Skripsi. Universitas Sebelas Maret Surakarta.

Karimah, 2016. Pengaruh Motivasi Belajar Terhadap Hasil Belajar Mahasiswa Jurusan Pendidikan Ekonomi angkatan 2012 Universitas Negeri Gorontalo.Skripsi. Universitas Negeri Gorontalo

Lubis, Ikhsan, Arfan., 2010. Akuntansi Keperilakuan Edisi 2. Penerbit Salemba Empat. Jakarta Selatan

Mahmud, Melizubaida.2015. Identifikasi Faktorfaktor yang Mempengaruhi Motivasi Belajar Mahasiswa pada Mata Kuliah Stenografi di Program Studi Pendidikan Ekonomi Perkantoran Fakultas Ekonomi Universitas Negeri Gorontalo.Jurnal Ilmu Pendidikan Non Formal. Universitas Negeri Gorontalo

Mudjiono dan Dimyati ,1994.Belajar dan Pembelajaran. Jakarta:Depdikbud.

M.Ngalim Purwanto, Drs, MP, 2007. Psikologi pendidikan, Bandung. PT. Remaja Rosdakarya

Mulyati. 2005. Psikologi Belajar. Yogyakarta: CV. Andi offset

Prayitno, Elida 1989. Motivasi dalam Belajar. Jakarta: Departemen Pendidikan dan Kebudayaan.

Rahmawati, Rima. 2016. Faktor-faktor yang Mempengaruhi Motivasi Belajar Siswa Kelas X SMA Negeri 1 Piyungan pada Mata Pelajaran Ekonomi Tahun Ajaran 2015/2016.(Skripsi). Universitas Negeri Yogyakarta

Riduwan, Dr. 2013. Belajar Mudah Penelitian untuk Guru - Karyawan Dan Peneliti Pemula. Penerbit Alfabeta. Bandung.

Santrock, W. John. 2008. Psikologi Pendidikan. Jakarta: Kencana. 
Sardiman, A.M 2011. Interaksi dan Motivasi Belajar Mengajar. Jakarta:PT. Raja Grafindo Persada

Sugiyono, 2011. Metode Penelitian Kuantitatif Kualitatif dan $R \mathcal{E}$ D. Bandung: CV Alfabeta

Soemanto, Wasty 1983. Psikologi Pendidikan. Malang: Rineka Cipta.

Syah, Muhibbin 1995. Psikologi Pendidikan dengan Pendekatan Terbaru. Bandung: PT Remaja Rosda Karya.
Uno, HB. 2008. Teori Motivasi dan Pengukurannya. Jakarta: PT. Bumi Persada.

Winkel, W.S 1996. Psikologi Pengajaran. Jakarta: Grafindo.

Zahroh, Fatimatus., 2014. Menguji Tingkat Pengetahuan Keuangan, Sikap Keuangan Dan Perilaku Keuangan Pribadi Mahasiswa Jurusan Manajemen Fakultas Ekonomika dan Bisnis Semester 3 Dan Semester 7. Laporan Penelitian. Semarang 